\title{
HOMONYMY AND THE COGNITIVE OPERATOR OF NORM IN GERMAN
}

\author{
Svitlana Kiyko \\ ORCID 0000-0003-4964-7043 \\ Scopus Author ID 36613142500 \\ s.kiyko@chnu.edu.ua \\ Yuriy Fedkovych National University of Chernivtsi, Ukraine \\ Yuriy Kiyko \\ ORCID 0000-0002-2251-2811 \\ Scopus Author ID 36613088300 \\ y.kiyko@chnu.edu.ua \\ Yuriy Fedkovych National University of Chernivtsi, Ukraine
}

Received February 1, 2020; Revised March 15, 2020; Accepted April 2, 2020

\begin{abstract}
The works of many linguists view homonymy as a negative phenomenon, which interferes with communication, complicates the perception of information, and decreases the effectiveness of the language as a means of communication. At the same time homonymy is a positive phenomenon which contributes to the compactness of the language, and allows to economize the units of the plain of content. The objective of our research is to determine the factors that differentiate the meaning of homonymic units, based on the broad factual material and psycholinguistic experiments. The components of intralinguistic homonymic rows based on the category of markedness, which correlates with the cognitive operator of norm / deviation. Among the criteria of markedness for homonymic differentiation are areal, social, chronological, and stylistic. The fact that one of the elements of the homonymic row is unmarked was proved by a number of psycholinguistic experiments, where we offered the German speakers to suggest the first association word which occurred to them referring the homonyms in the list. The experiment was carried out in a group of students from the Institute of German Studies, Technical University Chemnitz (Germany), aged 2125, whose native language is German. The psycholinguistic analysis shows that 97 per cent of homonymic pairs have both marked and unmarked components. This allows to explain homonymy from the point of view of the correlation of "markedness/unmarkedness", and wider "norm/deviation". From the cognitive point of view language markedness is derived from cognitive markedness, i.e. the unmarked language meaning corresponds to the cognitively normal (natural, expected) state of things, and the marked language meaning corresponds to cognitive deviation, i.e. unnatural, unexpected state of things. Normal state of things belongs to the cognitive image of human experience, and is conceptualized with the minimal mental calculating effort, i.e. is activated automatically; and deviations from this image require additional calculating resources for their activation. Thus, language markedness reflects cognitive operators of norm/deviation in the specific language means in language structures, including homonymic pairs and homonymic rows.
\end{abstract}

(C) Kiyko, Svitlana; Kiyko, Yuriy, 2020. This is an Open Access article distributed under the terms and conditions of the Creative Commons Attribution 4.0 International Licence (https://creativecommons.org/licenses/by/4.0/). East European Journal of Psycholinguistics, 7(1), 66-84. https://doi.org/10.29038/eejpl.2020.7.1.kiy 
Keywords: homonyms, homonymic row, markedness, cognitive operator of norm, German language.

Кійко Світлана, Кійко Юрій. Омонімія і когнітивний оператор норми в німецькій мові.

Анотація. У працях багатьох мовознавців омонімія розглядається як негативне явище, що перешкоджає спілкуванню, ускладнює сприйняття інформації і знижує ефективність мови як засобу комунікації. Водночас вважають, що омонімія сприяє компактності мови і дозволяє зекономити одиниці плану вираження. Мета нашого дослідження - встановити на широкому фактичному матеріалі 3 допомогою психолінгвістичного експерименту чинники, які диференціюють значення омонімів. На основі суцільної вибірки омонімів виявлено, що критеріями розмежування омонімів $є$ територіальна, соціальна, хронологічна і стилістична маркованість. 3 огляду на це, компоненти оморяду можна протиставити на основі категорії маркованості. Немаркованість одного 3 компонентів оморяду доведена в низці психолінгвістичних експериментів, у яких носіям німецької мови пропонували навести до омонімів у списку перше слово-асоціацію, яке спаде на думку. Матеріалом дослідження слугували 200 омопар іменників, вибраних на основі різної семантичної, стилістичної, хронологічної, територіальної або соціальної віднесеності одного з компонентів омопари. В експерименті взяли участь студенти Інституту германістики Технічного університету м. Хемніц (Німеччина) у віці від 21 до 25 років, рідна мова яких німецька. Результати експерименту свідчать про наявність у 97\% омопар маркованого і немаркованого компонентів. Мовна маркованість $\epsilon$ похідною від когнітивної маркованості, тобто немарковане мовне значення відповідає когнітивно нормальному (природньому) стану речей, а марковане мовне значення відповідає когнітивному відхиленню від нього. Нормальний стан речей входить до когнітивного гештальта людського досвіду і концептуалізується 3 мінімальною затратою ментальних обчислювальних зусиль, тобто активується автоматично, а відхилення від гештальта для їхньої активації вимагають додаткових ресурсів. Таким чином, мовна маркованість відображає лінгвоспецифічними засобами в омопарах i оморядах когнітивний оператор норми i відхилення від норми.

Ключові слова: омоніми, омопари, маркованість, когнітивний оператор норми, німецька мова.

\section{Introduction}

Linguistic studies of word meaning generally divide ambiguity into homonymy and polysemy. Homonymous words exhibit idiosyncratic variation, with essentially unrelated senses, e.g. bank as financial institution versus as natural object. The works of many linguists view homonymy as a negative phenomenon, which interferes with communication, complicates the perception of information, and decreases the effectiveness of the language as a means of communication. R. Bridges (2004) states that the language which has a lot of homonyms cannot be comfortable to speak, not to mention its scientific use. A. Reformatskiy (2004, p. 89) suggests that "all cases of homonyms mark the absence of precision of what must be precise". Homonymy is also characterized by L. Novikov (1982, p. 209) as an unnatural phenomenon that complicates communication. Homonymy erases the formal differences between the signs with different content, and distorts information. In order to avoid ambiguity the listener has to refer to the context, and it means that homonymic forms delay 
communicative process. The experimental research in the area of text perception shows that when given the sentence with the ambiguous elements, the time of the recipient's reaction to the message is considerably increased (Cairns, 1973; Ferreira, 2010; Foss \& Jenkins, 1973; Hogaboam \& Perfetti, 1975).

At the same time some researches think that homonymy is a positive phenomenon which contributes to the compactness of the language, and allows to economize the units of the plain of content (Mauler, 1983, p. 13). It is impossible to convey all the thoughts with only a dozen of sounds that is why homonymy is a natural language process. Investigating the mutual influence of the word's form and meaning, O. Ducháček (1953, p. 11) came to the conclusion that homonymy is not harmful for the language, which is confirmed by the existence of homonyms in practically every language. Moreover, the use of homonyms in literature serves various purposes, for instance, to form puns.

However, the quoted authors solve the problem of homonymy's benefits or drawbacks mostly in theory, citing only several most vivid examples, without the processing of the sufficient volume of material, in particular, without the consecutive analysis of homonyms in the unilingual dictionaries. The objective of our research is to review the categoric statements according to which homonymy causes interference in the process of communication, and to determine the factors that differentiate the meaning of homonymic units, based on the broad factual material.

\section{Methods}

The study is based on the consecutive analysis of homonyms selected from the Dictionary of the German Language Duden (2000), detailed with the dictionaries of Wahrig (2006), Bünting (2000), and Langenscheidt (2006). The object of the investigation is the homonymy of the Modern German nouns. The subject - the criteria of their differentiation in language and speech. The total number of studied homonyms is 2128 lexical units combined into 1018 homonymic rows. Most homonymic rows have two components, e.g. die Mutter "mother", die Mutter " "nut"; the total number of such pairs is 937 (1874 homonyms). We selected 72 three-component rows (216 homonyms), e.g. die Messe 1 "mass" (religious), die Messe ${ }^{2}$ "fair", die Messe ${ }^{3}$ "wardroom"; 8 four-component rows (32 homonyms), e.g. die Note "note" (musical), die Note $e^{2}$ "academic grade", die Note $e^{3}$ "diplomatic note", die Note $e^{4}$ "undertone" etc. There is also one six-component row: Atlas "one of the Titans", der Atlas ${ }^{2}$ "geographic atlas", der Atlas ${ }^{3}$ "neck vertebra”, der Atlas ${ }^{4}$ "satin”, der Atlas "telamon", der Atlas "the mountain in Africa" (Kiyko, 2016, p. 160-213).

The fact that one of the elements of the homonymic row (the first one as a rule) is unmarked was proved by a number of psycholinguistic experiments, where we offered the German speakers to suggest the first association word which occurred to them referring the homonyms in the list. This research was based on 200 homonymic pairs from our selection, chosen based on different semantic, stylistic, chronological, areal or 
social reference of one of the components of the pair. The questionnaire included both homogenic homonymic pairs whose homonyms have common origin, and heterogenic pairs, which coincide in sounding due to borrowing, incidental phonetic coincidence etc. Both homogenic and heterogenic pairs had 100 examples.

The experiment was carried out in a group of students from the Institute of German Studies, Technical University Chemnitz (Germany), aged 21-25, whose native language is German. As the number of examples was quite large (200), the questionnaires comprised 50 words each and the respondents were divided into four groups. The procedure was as follows: the instructions were given orally. It was required to write down the first word that occurred to the respondents as connected with the stimulus word.

\section{Results and Discussion}

It is a known fact that in the plane of content any homonymic group is characterized by the absence of the interlexemic semantic ties. It means that in most cases homonyms must belong to different lexico-semantic groups (LSGs), e.g.:

1) names of people referring to their place of their residence $\rightarrow$ names of dishes: Berliner ${ }^{1}$ "a citizen of Berlin" - Berliner ${ }^{3}$ "a doughnut with filling”, Wiener ${ }^{1}$ "a citizen of Vienna" - Wiener "Vienna sausage";

2) names of people referring to their age, gender, nationality, relations $\rightarrow$ names of dishes: Kanncker "an old man" - Knacker " "smoke-dried sausage"; Tatar " "Tatar" (nationality) - Tatar $^{2}$ "raw steak";

3) names of rivers $\rightarrow$ names of countries, lands, states, cities: der Ohio "the Ohio River" (the tributary of the Mississippi) - Ohio "Ohio" (the US state);

4) names of countries, states, lands $\rightarrow$ names of their capitals: Washington, Mexico;

5) names of animals $\rightarrow$ names of diseases: $\operatorname{Krebs}^{1}$ "crayfish” - Krebs ${ }^{2}$ “cancer", Star " "starling” - Star "cataract“;

6) names of animals $\rightarrow$ names of mechanic parts: Hahn "rooster" - Hahn " "water tap”, Döbel "a type of carp“ - Döbel ${ }^{2}$ "screw“;

7) names of cloth/fabric $\rightarrow$ types of clothing: Trikot ${ }^{1}$ "knitted fabric" - Trikot $^{1}$ "tights, leotard", Reversible "two-sided fabric" - Reversible "two-sided clothes" etc.

In our research $86 \%$ of all homonymic rows belong to different LSGs. It means that more than two-thirds of homonymic nouns are semantically differentiated based on the fact that they belong to different LSGs. 14\% of homonymic nouns (298 homonyms, 138 homonymic rows) belong to the same LSG. They are differentiated in various ways.

In most cases homonyms are differentiated with the help of grammatical gender, e.g. das Band" "strip" - der Band ${ }^{2}$ "book volume" - die Band " "band". Some nouns demonstrate gender fluctuations with the gradual change of gender, e.g.: der/das Warp ${ }^{1}$ "tight yarn" - der Warp " "grapnel", which proves the tendency to differentiate 
homonyms via the gradual change of grammatical gender. If the nouns belong to the same grammatical gender, different form of plural may be used for their differentiation (5 homonymic pairs), e.g. das Wort " "word" (plural Wörter) - das Wort ${ }^{2}$ (plural Worte) "cue, catchword". In other cases the decisive role in the differentiation of the complete homonymic nouns belongs to sociological, areal, stylistic or chronological aspects, i.e. the homonyms are differentiated via their belonging to different subsystems of lexis. Let us view these aspects in detail.

It is a known fact that the lexical system of any language comprises separate lexical subsystems:

1) from the sociological aspect: generally used, social-dialectal, and professional lexis;

2) from the areal aspect: nationwide and dialectal lexis;

3) from the stylistic aspect: literary and colloquial lexis;

4) from the chronological aspect: modern, archaic lexis, and neologisms.

Every lexical subsystem interacts with other subsystems; they penetrate one another, that is why it is not always easy to differentiate two subsystems. The subsystem of lexis is the scientific abstraction, the same as language as contrasted to speech. However, the notion of the subsystem helps to profoundly understand the complicated mechanism of the lexical system in general, and also to understand how homonyms are differentiated in the language system.

The greatest number of the complete lexical homonymic nouns is differentiated with the help of the restriction of the use of one of the homonyms by the areal dialect (16 homonymic pairs), e.g. der Flaum ${ }^{1}$ (areal) "lard" - der Flaum ${ }^{2}$ "fluff". Such homonyms are differentiated in areal aspect: one component of the homonymic pair is used only in a definite part of the German-speaking territory, and another one is a generally used word. For instance, dialectal words das Heck ${ }^{2}$ (Northern German) "pasture" and das Bord ${ }^{2}$ (Swiss) "slope, edge" are opposed to the generally used das Heck "stern" and das Bord" "shelf". If the speaker lives in the area where a homonym is not used, then the speaker of the literary norm has no homonymic opposition "dialectal : non-dialectal" because one member of the homonymic pair is actually missing. So, for the speakers of Northern German homonymy like der Kork ${ }^{1}$ "cork" (material) - der Kork ${ }^{2}$ (Southern German) "cork" will cause no misunderstanding in communication, as well as cases like die Kote ${ }^{2}$ (Northern German) "hut" - die Kote "tent" for Southern Germany. In the same manner speakers from Germany have no difficulty with communication due to the existence of the homonymic pairs like die Wegweisung "road sign" - die Wegweisung ${ }^{2}$ (Swiss) "deportation" etc., where one component of the pair is only used in Austria or Switzerland. When one of the homonyms is used in a definite area, then for the speaker of the literary standard its very dialectal nature is the decisive factor for homonymic differentiation. This eliminates the danger of homonymic clash in speech. From the point of view of the 
dialectal user the literary homonym does not interfere with the similarly sounding dialectal word due to the fact that they belong to different lexical subsystems.

It is interesting to note that the homonyms das College (in Britain) "college, private school of higher education" - das College ${ }^{2}$ (in France, Belgium) "college, higher school”, das Empire "empire" (in France during the times of Napoleon) - das Empire $^{2}$ "empire" (British colonies) are differentiated indicating the country of the origin of the corresponding notions. To some extent the differences between these homonyms may be viewed as areally conditioned, though here we have a case of false homonymy, similar to the interlanguage homonymy.

In 11 cases (22 homonyms) components of the homonymic pair belong to different social subsystems, i.e. one homonym is generally used, and another one belongs to terms or professional lexis, e.g. der Homo (biol.) "a member of the human species" - der Homo "gay". From the point of view of non-professionals homonymic groups of this type do not exist, as the speakers do not know one of the homonyms in the group. Professionals who theoretically know both homonyms do not mix them, as they usually correlate the professional term with only one object, the one usual for them. For instance, the mathematical term der $\operatorname{Graph}^{1}$ (math.) "graph, line" is strictly separated from the linguistic term der Graph ${ }^{2}$ (ling.) "letter" by the area of its use. Here are some examples of professional homonyms: 1) terms of chemistry: das Chlorit ${ }^{1}$ (chem.) "salt of the chlorine acid" - das Chlorit "chlorite“ (mineral); 2) naval terms: der Gast "guest" - der Gast ${ }^{2}$ (nav.) "sailor".

Misunderstanding may occur only in those cases where both homonyms are the terms of the same science, e.g. die Finne (zool.) "larva" - die Finne ${ }^{2}$ (zool.) "fin" (of a fish). To avoid ambiguity in such cases one homonym is substituted by its synonym, e.g. instead of die Finne "larva" the synonym die Larve is more frequently used (data based on the frequency dictionary Ruoff (2014)). One homonymic pair illustrates the differences in the plain of generally used: social-dialectal lexis: $\operatorname{der} \operatorname{Rex}^{1}$ "king" - der Rex $^{2}$ "headmaster".

Five homonymic pairs have their correlates among archaic lexis, i.e. they are differentiated in chronological aspect. Such homonyms have modern synonyms in the language system and thus they become obsolete, e.g. die Schnur - die Schwiegertochter "daughter-in-law". Some homonyms became obsolete because the notions they denote stopped playing any significant role in the life of modern society, e.g. die Lire "lira" (former Italian currency). Such homonyms are limited in their use to the spheres of historical novels and historical and cultural studies, and they have their homophone correspondents in modern lexis, e.g. der Real "real" (currency in Brazil), die Lire "lira" (Turkish currency). Archaic homonyms are separated from their similarly sounding correlates by the fact that they exist in a separate subsystem of lexis, e.g. die Schelle (arch.) "handcuff" - die Schelle (areal) "bell”.

Several homonyms differ from their homophone correlates in their stylistic aspect: one member of the homonymic row belongs to the subsystem of colloquial lexis, and 
another one - to literary: e.g. der Skater ${ }^{1}$ (coll.) "skater" (on skates) - der Skater ${ }^{2}$ "skater" (on a skateboard). The opposition of literary and colloquial is apparently sufficient for their differentiation, e.g. die Domina" "prioress" - die Domina (coll. euph.) "prostitute". One homonym is devoid of any coloring in the system of the language, i.e. is stylistically neutral, while the other one has negative stylistic coloring, which practically excludes their mixture in speech. Stylistic differentiation of the homophone words also works when one of them has positive stylistic coloring, or belongs to the elevated style, being, for instance, a poetic word. The homonymic correlate of such a word usually has no stylistic coloring, e.g. der Fels "rock" - der Fels $^{2}$ (poet.) "cliff”. Both types of stylistically colored words differ from the neutral lexis by their use in different spheres of speech: homonyms marked as "colloquial" are mostly used in oral speech, and poetic words - in verse, poems, ballads etc., while stylistically neutral homonyms are used in all types of text. In the language system they are separated by the limits of lexical subsystems.

Some complete homonyms are solely differentiated by the fact that one of the elements of the homonymic row is only used in set expressions, e.g. das Geschäft "shop" - das Geschäft ${ }^{2}$ (euph.) "bathroom deeds". The above cited criteria for homonymic differentiation are presented in Table 1:

Table 1

Criteria of Differentiation of the Homonymic Nouns

\begin{tabular}{|c|c|c|}
\hline $\begin{array}{c}\text { Criteria of } \\
\text { differentiation }\end{array}$ & $\begin{array}{l}\text { Number of } \\
\text { homonymic } \\
\text { rows }\end{array}$ & Examples \\
\hline $\begin{array}{l}\text { Belong to different } \\
\text { LSGs }\end{array}$ & 876 & $\begin{array}{l}\text { der Hahn" "rooster" - der Hahn² } \\
\text { "water tap" }\end{array}$ \\
\hline Areally marked & 16 & $\begin{array}{l}\text { der Flaum }{ }^{1} \text { (areal) "lard" - der } \\
\text { Flaum "fluff" }\end{array}$ \\
\hline Socially marked & 11 & $\begin{array}{l}\text { der Riemen"“belt” - der Riemen² } \\
\text { (nav.) “oar” }\end{array}$ \\
\hline $\begin{array}{l}\text { Chronologically } \\
\text { marked }\end{array}$ & 5 & $\begin{array}{l}\text { die Schelle }{ }^{1} \text { (arch.) "handcuffs" - die } \\
\text { Schelle "bell" }\end{array}$ \\
\hline Stylistically marked & 4 & $\begin{array}{l}\text { der Skater }{ }^{1} \text { (coll.) "skater" (on skates) } \\
\text { - der Skater "skater" (on a } \\
\text { skateboard) }\end{array}$ \\
\hline $\begin{array}{l}\text { Used in set } \\
\text { expressions }\end{array}$ & 3 & der Plan "action” - der Plan " “plan” \\
\hline Total & 1001 & \\
\hline
\end{tabular}


Other 17 homonymic rows (34 homonyms) completely coincide in their grammatical form and have no stylistic marking to differentiate them. Here belong toponyms (7 homonymic pairs), one of which denotes a country and another one - its capital: Mexiko "Mexico" (a country in the South America) - Mexiko "Mexico City". The analysis of publicistic texts shows that the differentiation of such nouns is based on the combinability of the homonyms denoting cities with the prepositions bei, bis or über, which are not used with the names of countries and lands, e.g.: Aus dem 30. Stock lässt sich der Blick über Singapur genießen (fr-aktuell.de 05.01.2005). Sometimes we may also observe the lexicalization of one of the homonyms, e.g. Mexiko-Stadt "Mexico City" as opposed to Mexico "Mexico" (the country), and in some cases the use of the names of cities and countries is specified, e.g.: Rechtzeitig zum Mozart-Jahr 2006 will die Stadt Salzburg etwa das ewige Rätsel um den Schädel Mozarts lösen (welt.de 07.01.2005).

In other cases the context is the main criterion of differentiation of the homonymic proper names, for instance, when a proper name is used in the sequence of other country or city names, which helps to understand the homonym, e.g. Die Redaktion sitzt nicht in Bangkok, Singapur oder Hongkong (fr-aktuell.de 05.01.2005) (the name of the city).

Other 10 pairs of complete lexical homonyms have no grammatical, sociological, areal, stylistic or chronological marking to help differentiate them. They also belong to the same LSG, e.g. der Bauer " "peasant" - der Bauer "builder" (LSG "Social status"), die Einladung "loading" - die Einladung "invitation", die Folge "sequence" - die Folge "consequence" (LSG "Abstract notions") etc. Their number is too small to cause any obstacles in communication ( $0,01 \%$ of all homonymic rows). Apparently, context (both linguistic and extra-linguistic) is the only criterion of their differentiation.

As we can see, the fact that most homonymic nouns belong to different LSGs, and that those belonging to the same LSG can be differentiated with the help of various grammatical indices and stylistic markings, allows to quite accurately differentiate their meaning. Regarding this the components of the homonymic row can be differentiated based on the category of markedness, which correlates with the cognitive operator of norm / deviation. It is a known fact that the linguistic notion of markedness is applied to various components of the language structure; it has high explanatory potential and cognitive value. The notion of markedness was derived from phonology and gained special value in the typological description of the asymmetry of grammatical parameters in the works of G. Greenberg (1966) and his followers (Croft, 2003, p. 87100). In grammar the marked (strong) member of the opposition has some formally expressed feature (e.g. plural of nouns) and narrower and more precise meaning than the unmarked one.

In the homonymic row, the homonym registered in the dictionary under №1 is as a rule unmarked, while the others are marked, i.e. they are limited in their use stylistically, chronologically, territorially or socially. This means that the homonymic 
row consists of marked and unmarked members. Strong members of the homonymic rows can be characterized as functionally limited lexis, which is opposed in their differential features to the active, generally used, neutral nominative language content. Moreover, the notion of "marked lexis" is much wider than that of "stylistically marked lexis": marked lexemes bear any additional (to their lexical meaning) information about the grammatical meaning, sphere of use, temporal reference, emotional and expressive coloring or functional stylistic use of the lexical units.

The results of psycholinguistic experiments were grouped and the frequency of use of each reaction word to the given stimulus word was calculated (see Table 2, where some examples are cited). In the Table 2 the $3^{\text {rd }}$ and $5^{\text {th }}$ columns contain dictionary definitions of every homonym to compare the obtained data. The frequency of occurrence of associate words is given in parentheses after the words.

Table 2

The List of Associations with the Various Components of the Homonymic Rows

\begin{tabular}{|c|c|c|c|c|c|}
\hline No & $\begin{array}{l}\text { Homonym } \\
\text { ic row }\end{array}$ & $\begin{array}{c}\text { The meaning of the } \\
1^{\text {st }} \text { component of } \\
\text { the homonymic } \\
\text { row }\end{array}$ & $\begin{array}{l}\text { The list of } \\
\text { associations }\end{array}$ & $\begin{array}{l}\text { The meaning } \\
\text { of the } 2^{\text {nd }} \\
\text { component }\end{array}$ & $\begin{array}{c}\text { The list of } \\
\text { associa- } \\
\text { tions }\end{array}$ \\
\hline 1 & Mutter & $\begin{array}{l}\text { Mutter }{ }^{1} \text {, die; -, } \\
\text { Mütter } \\
\text { 1. a) Frau, die } \\
\text { Kind(er) hat oder } \\
\text { erzieht; b) Vorste- } \\
\text { herin eines Klos- } \\
\text { ters; 2. weibliches } \\
\text { Tier, das Junge } \\
\text { geworfen hat; 3. } \\
\text { (Techn.) Matrize; } \\
\text { 4. (Jargon) } \\
\text { Muttergesellschaft }\end{array}$ & $\begin{array}{l}\text { Kind(er) (14), } \\
\text { Frau (9), Toch- } \\
\text { ter (3), Liebe } \\
\text { (2), Pflege, } \\
\text { Zuhause }\end{array}$ & $\begin{array}{l}\text { Mutter }^{2} \text {, die; } \\
\text {-, -n } \\
\text { Schrauben- } \\
\text { mutter }\end{array}$ & $\Sigma 0$ \\
\hline 2 & Gast & $\begin{array}{l}\text { Gast', der; -[e]s, } \\
\text { Gäste } \\
\text { 1. zur Bewirtung } \\
\text { eingeladene Per- } \\
\text { son; 2. a) Besu- } \\
\text { cher eines Lokals; } \\
\text { b) jmd., der gegen } \\
\text { Entgelt beherbergt } \\
\text { wird }\end{array}$ & $\begin{array}{l}\text { Besucher (12), } \\
\text { Ein ladung (4), } \\
\text { Wirt (2), einla- } \\
\text { den (2), Abend- } \\
\text { essen (2), Es- } \\
\text { sen, Hotel, Aus- } \\
\text { land, Tante, } \\
\text { Empfang, Ur- } \\
\text { laub, mitbrin- }\end{array}$ & $\begin{array}{l}\text { Gast }^{2} \text {, der; - } \\
\text { [e]s, -en } \\
\text { (Seemannsspr } \\
\text {.) Matrose }\end{array}$ & $\Sigma 0$ \\
\hline
\end{tabular}




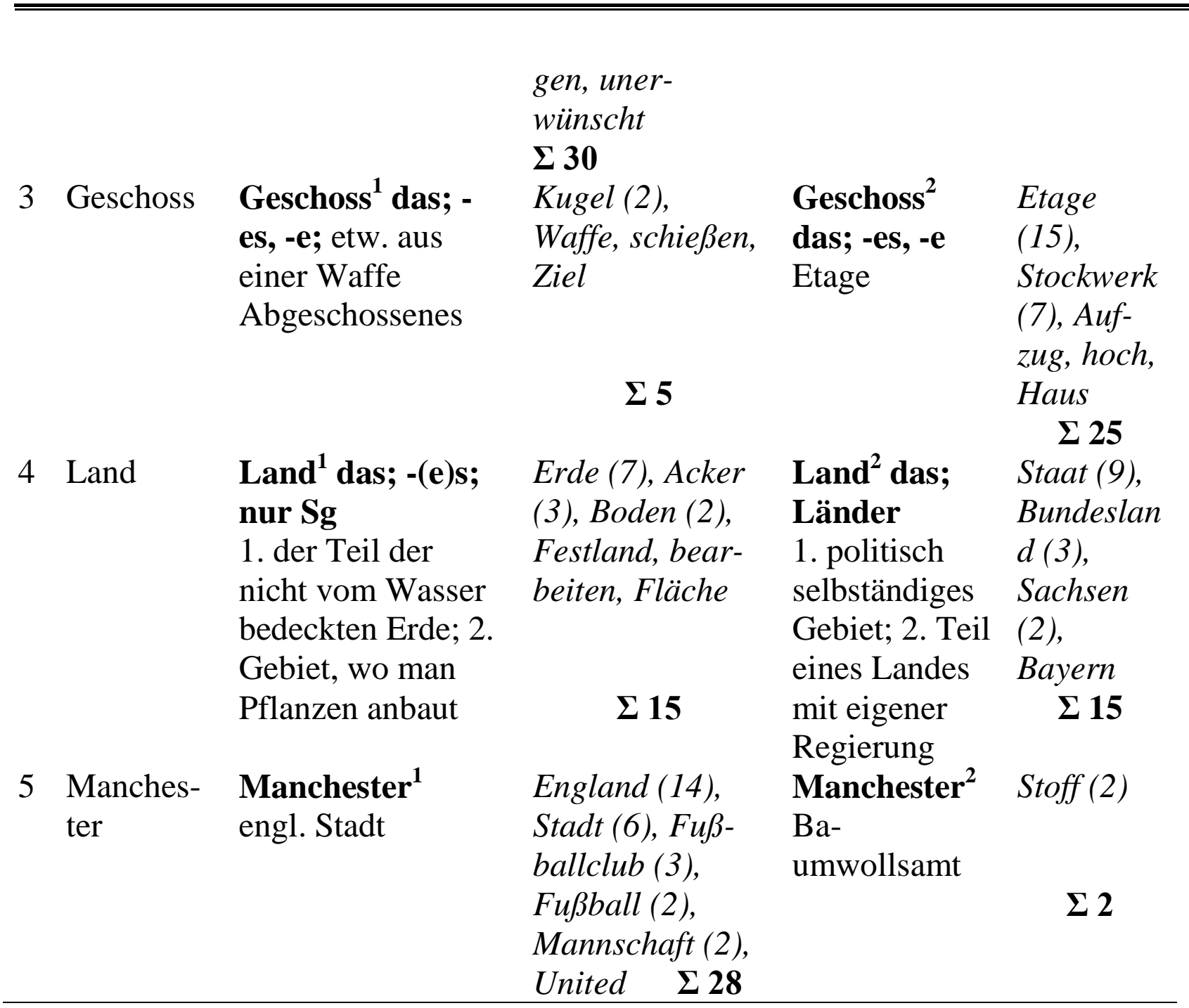

The obtained experimental data show that the homonym cited in the dictionary under №2 is mostly marked (75\%). In 200 homonymic pairs only $22 \%$ show that the first component of the pair is marked, e.g. der Kuli "cheap worker" (0 associates) and der Kuli " "ballpoint pen" (30 associates), der Rauch "thick fur" (0 associates) and der Rauch $^{2}$ "smoke" (30 associates). Pairs heterogenic in their origin prevail among the homonymic pairs with the first marked component (26 heterogenic pairs as opposed to 15 homogenic), which is apparently conditioned by the peculiarities of lexicographic practice. It is a known fact that in the homogenic pairs the most frequent component is cited first, which is not observed for the heterogenic pairs.

In seven cases (3\% of examples) the number of associations with the first and second component of the pair is approximately equal, e.g. das Land "dry land" and das Land "country" (15 associates), das Pflaster "cobblestone" (14 associates) and das Pflaster "plaster" (16 associates), etc.

We grouped the homonymic pairs according to the markedness of one of the components in the subgroup, and in each subgroup we calculated the relative number of the pairs with the marked components (when the ratio between the associates of the 
marked and unmarked component is 30 to 0 ). Thus, among the homonymic pairs with one socially marked component the relative portion of such homonymic pairs makes $75 \%$, i.e. we registered 25 homonymic pairs with the most marked component out of 33 homonymic pairs analyzed (see Table 3 ).

Table 3

Homonymic Rows with Socially Marked Components

\begin{tabular}{|c|c|c|c|c|}
\hline Homonymic row & $\begin{array}{c}\text { The } \\
\text { markedness of } \\
\text { the } 1^{\text {st }} \\
\text { component }\end{array}$ & $\begin{array}{l}\text { Number } \\
\text { of } \\
\text { associatio } \\
\text { ns }\end{array}$ & $\begin{array}{c}\text { The markedness } \\
\text { of the } 2^{\text {nd }} \\
\text { component }\end{array}$ & $\begin{array}{c}\text { Number of } \\
\text { association } \\
\text { s }\end{array}$ \\
\hline $\begin{array}{l}\text { Gast, Fall, Glas, } \\
\text { Riemen }\end{array}$ & - & 30 & navy & 0 \\
\hline Schütze & - & 30 & technical & 0 \\
\hline Pink & - & 30 & navy & 0 \\
\hline Stuhl & - & 30 & medicine & 0 \\
\hline Galle & - & 30 & $\begin{array}{l}\text { veterinary } \\
\text { medicine }\end{array}$ & 0 \\
\hline Schiff & - & 30 & architecture & 0 \\
\hline Dom & - & 30 & geology & 0 \\
\hline Drossel & - & 30 & engineering & 0 \\
\hline Flucht & - & 30 & construction & 0 \\
\hline Jäger & - & 30 & military & 0 \\
\hline Set & - & 30 & printing & 0 \\
\hline Kraut & - & 30 & soldiers language & 0 \\
\hline Locke & - & 30 & hunting & 0 \\
\hline Schmiere & - & 30 & criminal & 0 \\
\hline Karre & - & 30 & geology & 0 \\
\hline Post & - & 30 & basketball & 0 \\
\hline Riff & - & 30 & music & 0 \\
\hline Standard & - & 30 & Jazz jargon & 0 \\
\hline Popper & - & 30 & Jargon & 0 \\
\hline Stift & - & 28 & christl. church & 2 \\
\hline Stab & - & 27 & military & 3 \\
\hline Spannung & - & 26 & physics & 4 \\
\hline Hyazinth & - & 26 & greek mythology & 4 \\
\hline Lob & - & 26 & tennis, badminton & 4 \\
\hline Gesellschaft & - & 19 & economy & 11 \\
\hline Kreuzer & - & 11 & military & 19 \\
\hline Raute & - & 4 & geometry & 26 \\
\hline
\end{tabular}




\begin{tabular}{lcccc}
\hline \hline Neptun & $\begin{array}{c}\text { roman } \\
\text { mythology } \\
\text { roman }\end{array}$ & 27 & - & 3 \\
Venus & 24 & - & 6 \\
Viola & $\begin{array}{c}\text { motany } \\
\text { botan } \\
\text { Zettel }\end{array}$ & 18 & - & 12 \\
Rauch & $\begin{array}{c}\text { industry } \\
\text { technical } \\
\text { ntern }\end{array}$ & 0 & - & 30 \\
\hline
\end{tabular}

Here belong homonymic units used in the scientific (general scientific and branch terms, scientific and technical professionalisms), official (administrative, diplomatic and law terminology), publicistic (publicistic terms, socio-political lexis and terms), religious (religious lexis and terms) styles of the German language, as well as bookish lexical units, e.g. die Locke ${ }^{2}$ (hunting) "decoy", die Schmiere (criminal) "lookout". The common feature of these groups of words is their use as a means of communication of the separate social, professional and age groups of people.

The rest of the groups may be ranged as follows:

1) homonymic groups where one of the components is only used in set expressions: $100 \%$ (5:5). Here belong such examples as die Lampe ${ }^{2}$ (in the expression Meister Lampe) "Master Hare", der Onkel ${ }^{2}$ (in the expression großer/dicker Onkel) "toe” (see Table 4).

\section{Table 4}

Homonymic Rows with Components used in Set Expressions

\begin{tabular}{lcccc}
\hline $\begin{array}{c}\text { Homonym } \\
\text { ic row }\end{array}$ & $\begin{array}{c}\text { The markedness } \\
\text { of the } 1^{\text {st }} \\
\text { component }\end{array}$ & $\begin{array}{c}\text { Number of } \\
\text { association } \\
\text { s }\end{array}$ & $\begin{array}{c}\text { The markedness } \\
\text { of the } 2^{\text {nd }} \\
\text { component }\end{array}$ & $\begin{array}{c}\text { Number of } \\
\text { associations }\end{array}$ \\
\hline Lampe & - & 30 & in set expression & 0 \\
Klaue & - & 30 & in set expression & 0 \\
Onkel & - & 30 & in set expression & 0 \\
August & - & 30 & in the chance & 0 \\
Hummel & - & 30 & wellcoming call & 0 \\
\hline
\end{tabular}

2) homonymic groups where one component is shortened: $100 \%(1: 1)$. We only found one homonymic pair of this type: die Birne "pear" and die Birne "light bulb".

3) homonymic groups with one chronologically marked component: 83\% (5:6). Chronologically marked lexis includes obsolete words (archaic and historic), e.g. der Zelt $^{2}$ (arch.) "pass” (see Table 5). 
Table 5

Homonymic Rows with One Chronologically Marked Component

\begin{tabular}{lcccc}
\hline $\begin{array}{c}\text { Homonym } \\
\text { ic row }\end{array}$ & $\begin{array}{c}\text { The markedness } \\
\text { of the } 1^{\text {st }} \\
\text { component }\end{array}$ & $\begin{array}{c}\text { Number of } \\
\text { associations }\end{array}$ & $\begin{array}{c}\text { The markedness } \\
\text { of the } 2^{\text {nd }} \\
\text { component }\end{array}$ & $\begin{array}{c}\text { Number of } \\
\text { association } \\
\text { som }\end{array}$ \\
\hline Zelt & - & 30 & archaic & 0 \\
Hecke & - & 30 & archaic & 0 \\
Mandel & - & 30 & archaic & 0 \\
Schild & - & 27 & historic & 3 \\
Schock & archaic & 0 & - & 30 \\
Rad & formerly & 0 & - & 30 \\
\hline
\end{tabular}

4) homonymic groups with both components marked: 53\% (9:17). The components of the pair may be simultaneously marked socially, e.g. der Zyklon ${ }^{1}$ (meteorology) "cyclone" and das Zyklon" (chemistry) "a type of poisons gas", stylistically and areally, e.g. der Schamott ${ }^{1}$ (coll. derog.) "junk" and der Schamott ${ }^{2}$ (Austrian coll.) "a type of clay", chronologically and areally, e.g. das Panier $^{1}$ (arch.) “flag, banner” and die Panier ${ }^{2}$ (Austrian) "breading mass”, etc. (see Table 6)

Table 6

Homonymic Rows with Both Components Marked

\begin{tabular}{|c|c|c|c|c|}
\hline $\begin{array}{l}\text { Homonym } \\
\text { ic row }\end{array}$ & $\begin{array}{l}\text { The markedness of } \\
\text { the } 1^{\text {st }} \text { component }\end{array}$ & $\begin{array}{l}\text { Number of } \\
\text { association } \\
\mathrm{s}\end{array}$ & $\begin{array}{c}\text { The markedness } \\
\text { of the } 2^{\text {nd }} \\
\text { component }\end{array}$ & $\begin{array}{c}\text { Number } \\
\text { of } \\
\text { associatio } \\
\text { ns }\end{array}$ \\
\hline Zyklon & technical & 30 & chemistry & 0 \\
\hline Elektron & nuclear physics & 30 & chemistry & 0 \\
\hline Koma & medicine & 30 & education & 0 \\
\hline Schamott & colloquial pejorative & 30 & austrian colloquial & 0 \\
\hline Protz & colloquial & 30 & forestry & 0 \\
\hline Rumpel & south german & 30 & obsolescent & 0 \\
\hline Pastorale & $\begin{array}{c}\text { music; literature; } \\
\text { painting }\end{array}$ & 30 & kath. church & 0 \\
\hline Alternative & education & 28 & formerly & 3 \\
\hline Ramsch & colloquial pejorative & 27 & card game & 3 \\
\hline Pneumatik & physics, technology & 26 & austrian, swiss & 4 \\
\hline Demo & jargon & 17 & jargon & 13 \\
\hline Hutsche & $\begin{array}{l}\text { south german, } \\
\text { austrian }\end{array}$ & 9 & areal colloquial & 21 \\
\hline Penne & colloquial pejorative & 8 & school slang & 22 \\
\hline Hocke & nothern german & 4 & sports & 26 \\
\hline
\end{tabular}




\begin{tabular}{lcccc} 
Panier & high & 3 & austrian & 27 \\
Hascher & austrian colloquial & 0 & colloquial & 30 \\
Soll & geology & 0 & banking & 30 \\
\hline
\end{tabular}

5) homonymic groups with one areally marked component: 52\% (11:21). This group is represented by the words with clear dialectal reference, e.g. die Beige ${ }^{2}$ (Southern German, Swiss) "pile”, die Pflaume ${ }^{2}$ (areal) “mockery” (see Table 7).

Table 7

Homonymic Rows with One Areally Marked Component

\begin{tabular}{|c|c|c|c|c|}
\hline Homonymic row & $\begin{array}{c}\text { The } \\
\text { markedness } \\
\text { of the } 1^{\text {st }} \\
\text { component }\end{array}$ & $\begin{array}{c}\text { Number } \\
\text { of } \\
\text { associatio } \\
\text { ns }\end{array}$ & $\begin{array}{c}\text { The markedness } \\
\text { of the } 2^{\text {nd }} \\
\text { component }\end{array}$ & $\begin{array}{l}\text { Number } \\
\text { of asso- } \\
\text { ciations }\end{array}$ \\
\hline Kabel & - & 30 & Northern German & 0 \\
\hline Mull, Heck & - & 30 & Northern German & 0 \\
\hline Erkenntnis & - & 30 & Austrian, Swiss & 0 \\
\hline Felge, Pflaume & - & 30 & Areal & 0 \\
\hline $\begin{array}{l}\text { Doppel, } \\
\text { Wegweisung }\end{array}$ & - & 30 & Swiss & 0 \\
\hline Beige & - & 30 & $\begin{array}{c}\text { Southern German, } \\
\text { Swiss }\end{array}$ & 0 \\
\hline Loch & - & 30 & in Schottland & 0 \\
\hline Mangel & - & 29 & $\begin{array}{c}\text { Southern German, } \\
\text { Swiss }\end{array}$ & 1 \\
\hline Riese & - & 29 & $\begin{array}{c}\text { Southern German, } \\
\text { Austrian }\end{array}$ & 1 \\
\hline Paps & - & 28 & areal & 2 \\
\hline Matte & - & 28 & Swiss & 2 \\
\hline Office & - & 27 & Swiss & 3 \\
\hline Hafen & - & 25 & $\begin{array}{l}\text { Southern German, } \\
\text { Austrian, Swiss }\end{array}$ & 5 \\
\hline Stoppel & - & 25 & Austrian & 5 \\
\hline Stollen & - & 5 & Austrian, Swiss & 25 \\
\hline Strudel & - & 3 & $\begin{array}{c}\text { Southern German, } \\
\text { Austrian }\end{array}$ & 27 \\
\hline Muff & $\begin{array}{l}\text { Northern } \\
\text { German }\end{array}$ & 17 & - & 13 \\
\hline Rummel & areal & 0 & - & 30 \\
\hline
\end{tabular}


6) homonymic groups with one stylistically marked component: $25 \%$ (5:17). This group is represented by the words which, apart from their objective notional meaning, have components of subjective character: emotion, expression, imagery, evaluation. According to the emotional and expressive coloring connotatively marked lexis is divided into positively and negatively colored. Elevated, rhetorical words, lexical units with the emotional approval, and some joke lexemes bear positive emotional charge, e.g. die Hochzeit ${ }^{2}$ (humorous) "flourish", der Reif ${ }^{2}$ "wedding ring” etc. Negative evaluation is characteristic for colloquial words, which are differentiated according to the level of pejoration - from humorously ironic and familiar to rude and vulgar (expressive colloquialism), e.g. der Schwindel ${ }^{2}$ (coll. vulgar) "fraud”, die Raserei ${ }^{2}$ (coll. vulgar) "races” (see Table 8).

Table 8

Homonymic Rows with One Stylistically Marked Component

\begin{tabular}{|c|c|c|c|c|}
\hline $\begin{array}{c}\text { Homonymic } \\
\text { row }\end{array}$ & $\begin{array}{c}\text { The markedness } \\
\text { of the } 1^{\text {st }} \\
\text { component }\end{array}$ & $\begin{array}{c}\text { Number of } \\
\text { association } \\
\mathrm{s}\end{array}$ & $\begin{array}{c}\text { The markedness } \\
\text { of the } 2^{\text {nd }} \\
\text { component }\end{array}$ & $\begin{array}{c}\text { Number of } \\
\text { association } \\
\mathrm{s}\end{array}$ \\
\hline Juwel & - & 30 & expressive & 0 \\
\hline Tor & - & 30 & high & 0 \\
\hline Hochzeit & - & 30 & high & 0 \\
\hline Blüte & - & 30 & colloquial & 0 \\
\hline Diktat & - & 28 & colloquial & 2 \\
\hline Träne & - & 28 & $\begin{array}{c}\text { colloquial } \\
\text { vulgar }\end{array}$ & 2 \\
\hline Korn & - & 28 & colloquial & 3 \\
\hline Kater & - & 24 & colloquial & 6 \\
\hline Kohle & - & 20 & colloquial & 10 \\
\hline Reif & - & 19 & high & 11 \\
\hline Schwindel & - & 18 & $\begin{array}{c}\text { colloquial } \\
\text { vulgar }\end{array}$ & 12 \\
\hline Mittag & - & 16 & colloquial & 14 \\
\hline Raserei & - & 14 & $\begin{array}{l}\text { colloquial } \\
\text { vulgar }\end{array}$ & 16 \\
\hline Horde & - & 3 & $\begin{array}{c}\text { colloquial } \\
\text { vulgar }\end{array}$ & 27 \\
\hline Kuli & - & 0 & colloquial & 30 \\
\hline Laster & colloquial & 13 & - & 17 \\
\hline Bückling & $\begin{array}{l}\text { colloquial } \\
\text { humorous }\end{array}$ & 7 & - & 23 \\
\hline
\end{tabular}


7) homonymic groups with components without marking: 29\% (28:96). In this group the number of associates is influenced by the frequency of the word's use, i.e. the words with greater frequency get more associates, e.g. die Mutter " "mother" (30 associates) and die Mutter " "nut" (0 associates) (see Table 9).

Table 9

Homonymic Rows with Components without Marking

\begin{tabular}{|c|c|c|}
\hline Homonymic rows & $\begin{array}{l}\text { Number of } \\
\text { associations to } \\
\text { the } 1^{\text {st }} \\
\text { component }\end{array}$ & $\begin{array}{l}\text { Number of } \\
\text { associations } \\
\text { the } 2^{\text {nd }} \\
\text { component }\end{array}$ \\
\hline $\begin{array}{l}\text { Mutter, Pony, Moment, Wende, Pol, Drilling, } \\
\text { Mantel, Mund, Bulle, Lippe, Mine, Zoll, } \\
\text { Messer, Hering, Flur, Pause, Verfassung, Bart, } \\
\text { Aufgabe, Umschlag, Ente, Presse, Spur }\end{array}$ & 30 & 0 \\
\hline Chor & 29 & 1 \\
\hline $\begin{array}{l}\text { Schneider, Manchester, Fliege, Taube, Bremse, } \\
\text { Militär, Batterie }\end{array}$ & 28 & 2 \\
\hline Angel, Bruch, Ball, Flügel, Puppe, Handlung & 27 & 3 \\
\hline $\begin{array}{l}\text { Technik, Hütte, Geschick, Marsch, Rat, } \\
\text { Wechsel }\end{array}$ & 26 & 4 \\
\hline $\begin{array}{l}\text { Pech, Boden, Fliege, Trieb, Kombination, } \\
\text { Schwarm, Mühle }\end{array}$ & 25 & 5 \\
\hline Wurf, Galerie, Schöpfer, Espresso, Laube & 24 & 6 \\
\hline Schnitzel, Magazin & 23 & 7 \\
\hline Gericht, Lösung, Weihe & 22 & 8 \\
\hline Mal & 20 & 10 \\
\hline Seite, Steuer, Krebs, Kiefer & 19 & 11 \\
\hline Rock, Futter & 18 & 12 \\
\hline Linse, Stoß & 17 & 13 \\
\hline Bogen, Fessel, Leiter & 16 & 14 \\
\hline Land, Strom & 15 & 15 \\
\hline Pflaster & 14 & 16 \\
\hline Bahn, Rost & 12 & 18 \\
\hline Pension & 11 & 19 \\
\hline Plastik & 10 & 20 \\
\hline Rolle & 9 & 21 \\
\hline See, Schalter & 8 & 22 \\
\hline Ton & 7 & 23 \\
\hline Geschoss, Weide & 5 & 25 \\
\hline
\end{tabular}


Ruhr, Bildung

Auflauf, Ordner

Dichtung

Kongo

Scharlach, Pickel, Wetter, Kaschmir, Einladung

The results of the psycholinguistic experiment show that the components of the homonymic pairs that are used in set expressions, shortened or chronologically marked, are the most marked. The least marked are those components that are cited in the dictionary without any stylistic marking, or they belong to the connotatively marked lexis, i.e. have emotional and expressive coloring.

\section{Conclusions}

The psycholinguistic analysis we carried out shows that the predominate number of homonymic pairs ( $97 \%$ of our selection) have marked and unmarked components. This allows to explain homonymy from the point of view of the cognitive-language correlation of "markedness/unmarkedness", and wider - "norm/deviation". From the cognitive point of view language markedness is derived from cognitive markedness, i.e. the unmarked language meaning corresponds to the cognitively normal (natural, expected) state of things, and the marked language meaning corresponds to cognitive deviation, i.e. unnatural, unexpected state of things. As stated by A. Kibrik (2008, p. 62), normal state of things belongs to the cognitive image of human experience, and is conceptualized with the minimal mental calculating effort, i.e. is activated automatically; and deviations from this image require additional calculating resources for their activation. Thus, language markedness reflects cognitive operators of norm/deviation in the specific language means in language structures, including homonymic pairs and homonymic rows. The presence of marked and unmarked elements in the homonymic pair or row in its turn demonstrates the synergetic potency of homonymy.

The prospects of the further research lie in the studies of the influence of cognitive-language correlation "norm/deviation" based on the consecutive analysis of homonyms of other parts of speech, primarily verbs and adjectives.

\section{References}

Bridges, R.S. (2004). On English Homophones. Society for Pure English Tract 02. Oxford: Clarendon Pr. Retrieved from http://www.gutenberg.org/files/14227/14227-h/14227-h.htm.

Cairns, H.S. (1973). Effects of bias on processing and reprocessing of lexically ambiguous sentences. Journal of Experimental Psychology, 97, 337-343. Retrieved from https://psycnet.apa.org/doi/10.1037/h0034098

Croft, W. (2003). Typology and universals. 2-d ed. Cambridge: Cambridge University Press. 
Ducháček, O. (1953). O vzájemném vlivu tvaru a významu slov. Praha: Státní pedagogické nakladatelství.

Ferreira, L. (2010). Metaphor comprehension in foreign language. In L. Scliar-Cabral, (Ed). Psycholinguistics: Scientific and Technological Challenges. (pp. 84-98). Porto Alegre: EDIPUCRS,

Foss, D.J. \& Jenkins C.M. (1973). Some effects of context on the comprehension of ambiguous sentences. Journal of Verbal Learning and Verbal Behavior, 12, 577-589. Retrieved from https://psycnet.apa.org/doi/10.1016/S0022-5371(73)80037-4

Greenberg, J. (1966). Language universals, with special reference to feature hierarchies. The Hague: Mouton.

Hogaboam, T.W. \& Perfetti, C.A. (1975). Lexical ambiguity and sentence comprehension. Journal of Verbal Learning and Verbal Behaviour, 14, 265-274. Retrieved from https://psycnet.apa.org/doi/10.1016/ S0022-5371(75)80070-3

Кибрик А.Е. Лингвистическая реконструкция когнитивной структуры. Вопросы языкознания. 2008. № 4. С. 51-77.

Кійко С.В. Синергетика омонімії як мовного, мовленнєвого і міжмовного явища. Чернівці : Родовід, 2016.

Маулер Ф.И. Грамматическая омонимия в современном английском языке. Ростов : Изд. Рост. университета, 1983.

Новиков Л.А. Семантика русского языка. М. : Высшая Школа, 1982.

Реформатский А.А. Введение в языкознание. 5 изд. М. : Аспект Пресс Press, 2004.

Ruoff, A. (2014). Häufigkeitswörterbuch gesprochener Sprache. 2. Auflage. Berlin: de Gruyter. Reprint 2014. https://doi.org/10.1515/9783110916058

\section{References (translated and transliterated)}

Bridges, R.S. (2004). On English Homophones. Society for Pure English Tract 02. Oxford: Clarendon Pr. Retrieved from http://www.gutenberg.org/files/14227/14227-h/14227-h.htm

Cairns, H.S. (1973). Effects of bias on processing and reprocessing of lexically ambiguous sentences. Journal of Experimental Psychology, 97, 337-343. Retrieved from https://psycnet.apa.org/doi/10.1037/h0034098

Croft, W. (2003). Typology and universals. 2-d ed. Cambridge: Cambridge University Press.

Ducháček, O. (1953). O vzájemném vlivu tvaru a významu slov. Praha: Státní pedagogické nakladatelství.

Ferreira, L. (2010). Metaphor comprehension in foreign language. In L. Scliar-Cabral, (Ed). Psycholinguistics: Scientific and Technological Challenges. (pp. 84-98). Porto Alegre: EDIPUCRS.

Foss, D.J. \& Jenkins C.M. (1973). Some effects of context on the comprehension of ambiguous sentences. Journal of Verbal Learning and Verbal Behavior, 12, 577-589. Retrieved from https://psycnet.apa.org/doi/10.1016/S0022-5371(73)80037-4

Greenberg, J. (1966). Language universals, with special reference to feature hierarchies. The Hague: Mouton.

Hogaboam, T.W. \& Perfetti, C.A. (1975). Lexical ambiguity and sentence comprehension. Journal of Verbal Learning and Verbal Behaviour, 14, 265-274. Retrieved from https://psycnet.apa.org/doi/10.1016/ S0022-5371(75)80070-3

Kibrik, A.E. (2008). Lingvističeskaya rekonstrukciya kognitivnoy struktury [Linguistic reconstruction of cognitive structure]. Voprosy Yazykoznaniya, 4, 51-77. 
Kiyko, S.V. (2016). Synergetyka omonimii yak movnoho, movlennevoho i moshmovnoho yavyshcha. [Synergy of homonymy as language, speech and interlanguage phenomenon]. Chernivtsi: Rodovid.

Mauler, F.I. (1983). Grammatičeskaya omonimiya v sovremennom angliyskom yazyke [Grammatical homonymy in Modern English]. Rostov: Rostov University Publishers.

Novikov, L.A. (1982). Semantika russkogo yazyka [Semantics of Russian language]. Moscow: Vys. Shkola.

Reformatskiy, A.A. (2004). Vvedeniye v Yazykoznaniye [Introduction to Linguistics]. 5th ed. Moscow: Aspekt Press.

Ruoff, A. (2014). Häufigkeitswörterbuch gesprochener Sprache. 2. Auflage. Berlin: de Gruyter. Reprint. https://doi.org/10.1515/9783110916058 